\title{
Seismic profile analysis of the Kangra and Dehradun re-entrant of NW Himalayan Foreland thrust belt, India: A new approach to delineate subsurface geometry
}

\author{
Joyjit Dey ${ }^{1}$, R Jayangonda Perumal ${ }^{2, *}$, Subham Sarkar ${ }^{3}$ and Anamitra Bhowmik ${ }^{4}$ \\ ${ }^{1}$ Indian Institute of Technology Kharagpur, Kharagpur 721 302, India. \\ ${ }^{2}$ Wadia Institute of Himalayan Geology, Dehradun 248 001, India. \\ ${ }^{3}$ Presidency University, Kolkata 700 073, India. \\ ${ }^{4}$ Jadavpur University, Jadavpur, Kolkata 700 032, India. \\ *Corresponding author. e-mail: ramperu.jayan@gmail.com
}

MS received 9 August 2016; revised 21 February 2017; accepted 6 April 2017; published online 31 August 2017

In the NW Sub-Himalayan frontal thrust belt in India, seismic interpretation of subsurface geometry of the Kangra and Dehradun re-entrant mismatch with the previously proposed models. These procedures lack direct quantitative measurement on the seismic profile required for subsurface structural architecture. Here we use a predictive angular function for establishing quantitative geometric relationships between fault and fold shapes with 'Distance-displacement method' ( $\mathrm{D}-\mathrm{d}$ method). It is a prognostic straightforward mechanism to probe the possible structural network from a seismic profile. Two seismic profiles Kangra-2 and Kangra-4 of Kangra re-entrant, Himachal Pradesh (India), are investigated for the fault-related folds associated with the Balh and Paror anticlines. For Paror anticline, the final cut-off angle $\beta=35^{\circ}$ was obtained by transforming the seismic time profile into depth profile to corroborate the interpreted structures. Also, the estimated shortening along the Jawalamukhi Thrust and Jhor Fault, lying between the Himalayan Frontal Thrust (HFT) and the Main Boundary Thrust (MBT) in the frontal fold-thrust belt, were found to be 6.06 and $0.25 \mathrm{~km}$, respectively. Lastly, the geometric method of fold-fault relationship has been exercised to document the existence of a fault-bend fold above the Himalayan Frontal Thrust (HFT). Measurement of shortening along the fault plane is employed as an ancillary tool to prove the multi-bending geometry of the blind thrust of the Dehradun re-entrant.

Keywords. Himalayan tectonics; himalayan frontal thrust (HFT); main boundary thrust (MBT); fault related folds.

\section{Introduction}

Hydrocarbon exploration started in the Kangra region (Himachal Pradesh, India) in 1956, when a well near Jawalamukhi produced non-commercial thermogenic gas along with highly saline water. The Jhor Fault within the Balh anticline was also associated with saline springs and feeble gas shows. But all efforts to delineate the gas failed, as a lot of drilling around Jawalamukhi did not give commercial success due to the insufficient knowledge of intricate structural architecture in the subsurface. Also, in the frontal fold belts of NW Sub-Himalaya, several discrepancies have 
been encountered in the surface and subsurface structural interpretation during hydrocarbon exploration. The regional behaviour of the surface elements is mainly biased either by thick-skinned (Raiverman et al. 1983, 1993; Raiverman 2002) or thin-skinned tectonics (Srivastava and Mitra 1994; Powers et al. 1998). The subsurface features investigated in the Kangra re-entrant (along K4 and K2 in figure 1) interprets wrench faults as the master fault at the pre-Tertiary level that branches upward in the form of reverse faults below the Balh anticline, with dips of the fault planes varying between $35^{\circ}$ to $60^{\circ}$ and, also, two faults at both the ends of Paror anticline as positive flower structures with fault dips varying between $45^{\circ}$ to $60^{\circ}$ (Raiverman et al. 1994; Raiverman 2002). This faults are having abrupt geometry, some emerges as fore faults whereas others form back structure, while branching in upward direction. On the contrary, Power et al. (1998) restored the section and interpreted the same seismic profile across the Balh and Paror anticlines as fault related folds. Hence, precise understanding of subsurface structural framework remained indeterminate.

Fault-bend folds (FBF), fault-propagation folds (FPF) and fault-detachment folds (FDF) are the three distinct modes of sub-surface structures in the foreland thrust belt (like in Himalayas, where normal faulting and other extensional features would be less expected, Misra and Mukherjee

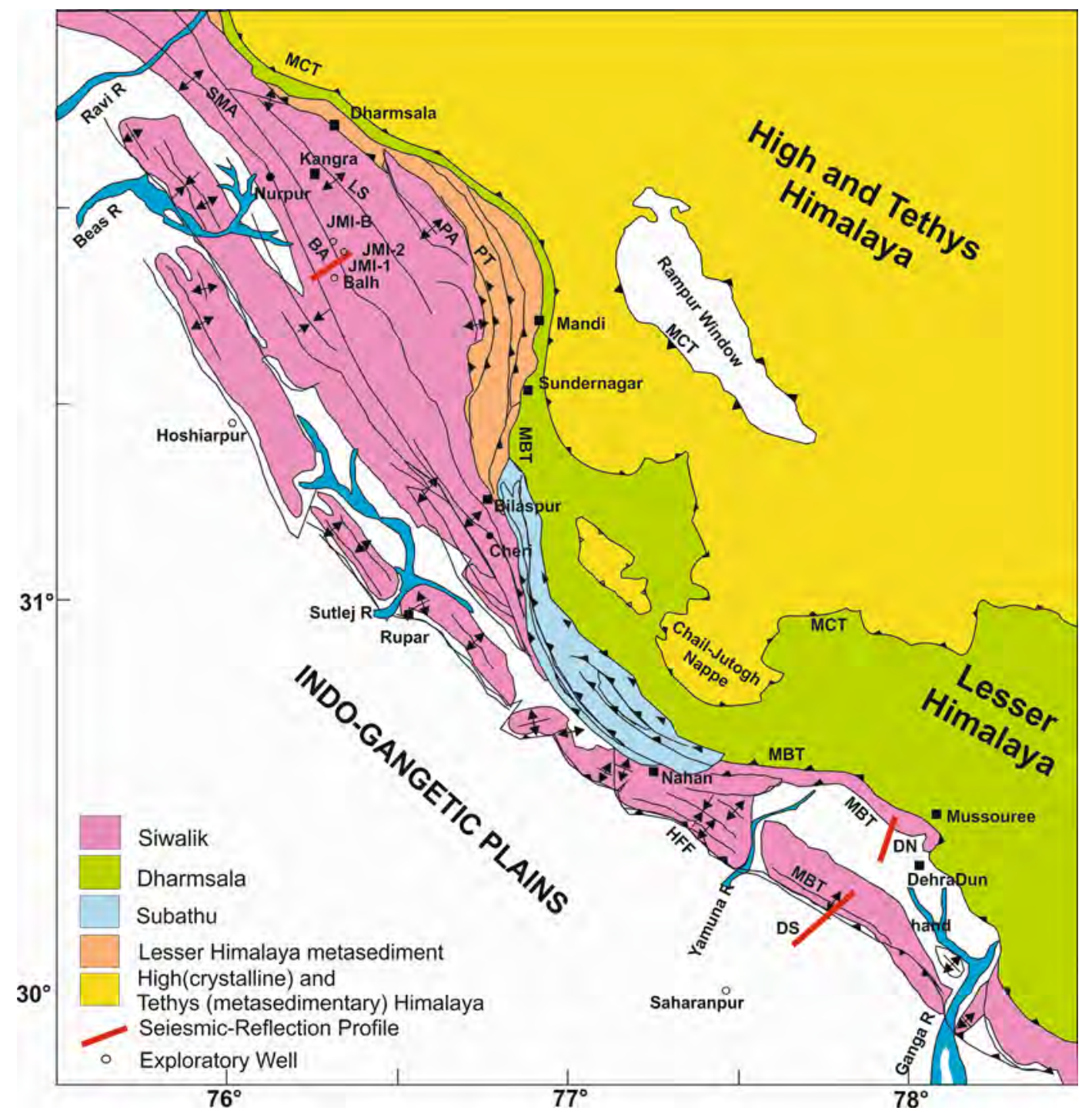

Figure 1. Geological map of part of the Sub-Himalaya in India (Inset), showing different lithological units (after Powers et al. 1998; Karunakaran and Ranga Rao 1976). Note the area of investigation for Kangra (K2 and K4) and Doon re-entrant (DS). Structure: BA: Balh anticline, BGT: Bhimgoda thrust, BrT: Barsar thrust, HFF: Himalayan Frontal fault, JMT: Jawalamukhi thrust, LS: Lambargaon syncline, MBT: Main Boundary thrust, MCT: Main Central thrust, PA: Paror anticline, SMA: Suruin-Mastgarh anticline. Seismic refection profiles: DN: Doon-N, DS: Doon-S, K2: Kangra-2, K4: Kangra-4. 
2017). Suppe (1983) proposed a suite of curves for Fault Bend Folds (FBF) relating the fold inter-limb angle to the upper and lower ramp angles. Similar quantitative relations have also been obtained for fault-propagation folds (FPF) (Suppe et al. 1990). Here, a method has been established to investigate existence of individual fold and fault using geometric relation between fold shape and fault geometry. Also, we have re-examined fault related folds from the seismic profiles provided by Oil Natural Gas Corporation (ONGC) for south of Kangra re-entrant (K2 and K4) and south of Dehradun valley (DS) (figure 1). Applying the distance-displacement method (Williams and Chapman 1983; Jayangondaperumal et al. 2013) as an ancillary tool on the same seismic section, we deduce an unequivocal structural profile based on relative propagation rates of fault and folds. It also checks the efficacy of previously modelled profiles using angular balancing method. We refer to both these methods as 'geometric test'. These methods have so far not been applied directly on seismic profiles to testify fault related folds like FBF and
FPF in any segment of the Himalaya. This helps to understand the relation between the surface fold growth and the subsurface tectonics.

\section{Stratigraphy and structural framework}

The Himalaya represents convergence between the Indian and the Eurasian plates, where Indus Tsangpo Suture Zone (ITSZ) marks the palaeogene collision. Continued convergence progressively migrated to the south in an in-sequence motion forming linear zones of deformation like the Main Central Thrust (MCT) and the Main Boundary Thrust (MBT), respectively (figure 1, Zhao et al. 1993; Mukherjee 2009, 2013a,b, 2015a,b; Mukherjee and Koyi 2010a,b; Mukherjee et al. 2012, 2013; Dubey 2014). The last structure to be formed, as a result of the last major Himalayan orogeny starting from the middle Pleistocene (Wadia and West 1964), was the foreland basin encompassing the Siwalik molasse (table 1) (Gansser 1964; Nakata 1972; Yin et al. 2006). The Main Frontal Thrust (MFT) or the Himalayan Frontal Thrust

Table 1. Simplified stratigraphy of the Himalayan Foreland, India (general descriptions modified after Thakur 1992; Karunakaran and Ranga Rao 1976; Najman et al. 1993).

\begin{tabular}{|c|c|c|}
\hline Absolute age & Formation & Lithological description \\
\hline Pliestocene & Neogal & $\begin{array}{l}\text { Conglomerates derived from plains and duns, } \\
\text { along with river terrace and glacio-fluvial } \\
\text { deposits derived from Himalayan Foothills }\end{array}$ \\
\hline Pliocene & Upper Siwalik & $\begin{array}{l}\text { Conglomerate with increasing sandstone content } \\
\text { away from Main Boundary Thrust, along with } \\
\text { some calcite cementation and interbedded with } \\
\text { siltstone and clayey layers }\end{array}$ \\
\hline Miocene & Middle Siwalik & $\begin{array}{l}\text { Minor claystone occurences in sandstones, } \\
\text { conglomeratic deposits more towards Main } \\
\text { Boundary Thrust and kyanite appears as a } \\
\text { marker for this horizon }\end{array}$ \\
\hline Miocene & Lower Siwalik & $\begin{array}{l}\text { Sandstone and claystone alterations with minor } \\
\text { silt and pebble horizons }\end{array}$ \\
\hline Miocene & Upper Dharmsala & $\begin{array}{l}\text { Greenish grey sandstones with very little amount } \\
\text { of claystone }\end{array}$ \\
\hline Oligocene & Lower Dharmsala & $\begin{array}{l}\text { Purple shale and siltstone present with minor } \\
\text { aranaceous content }\end{array}$ \\
\hline Upper Palaeocene to Eocene & Subathu Group & $\begin{array}{l}\text { Red and green shale, with minor sandstone and } \\
\text { limestone }\end{array}$ \\
\hline Cretaceous to Lower Palaeocene & Singati Formation & Limestone \\
\hline Cambrian & Vindhyan Group & $\begin{array}{l}\text { Partially and weakly metamorphosed sandstones, } \\
\text { siltstones and limestones }\end{array}$ \\
\hline Pre-Cambrian & Delhi and Aravalli Groups & $\begin{array}{l}\text { Arkosic sandstone, calcareous and garnetiferous } \\
\text { schist along with some amounts of associated } \\
\text { marble }\end{array}$ \\
\hline
\end{tabular}


(HFT) is the southernmost fault, which bounds this Siwalik strata. In most places, the HFT is a blind thrust. Thus, the strain released is manifested as anticlinal folding (Yeats and Lillie 1991; Yeats et al. 1992). It is generally assumed that thinskinned tectonics in the sub-Himalaya is taking place along a detachment thrust that dips gently northward (Seeber et al. 1981; Jayangondaperumal et al. 2013).

The NW Sub-Himalaya that extends almost uninterrupted throughout its length (Di Pietro et al. 2004; Yin 2006) has gained popularity among scientists and has been studied thoroughly. This is the active deformational front that multiplies in the recent past, posing hazardous earthquakes. Understanding the active tectonics is significant as it helps to analyse the nature of deformation in the Quaternary Period. A large number of recesses (or re-entrants), has formed in the NW Sub-Himalaya by the effects of basement wedges in the underlying Indian plate (Karunakaran and Ranga Rao 1976). Of these, notable are the Kangra and the Dehradun re-entrants within the active Himalayan orogen. South of Kangra, the Sub-Himalaya widens to $80 \mathrm{~km}$ due to this re-entrant (Dubey et al. 2004), which is bound by the MBT to the north and by the Indo-Gangetic plains to the south. Figure 1 shows location of two seismic profiles of $\mathrm{K} 2$ and $\mathrm{K} 4$ along NE-SW direction across the Kangra re-entrant. The re-entrant principally consists of active faults of $4-8 \mathrm{~km}$ depth beneath the folded beds (Thakur et al. 2014) and can be considered to have three main domains, viz., the northern, central and southern structures (Powers et al. 1998). In the southern part adjacent to the Indo-Gangetic plains, the south-vergent HFT and the Soan Thrust formed broad anticlines and synclines exhibiting little internal deformation by thrusting Upper Siwalik rocks to the surface, e.g., Janauri anticline (JA) (figure 1). Seismic profile of K2 contains Siwalik strata in the right stepping Balh anticline that exhibits complex deformation and is truncated to its north by the Jawalamukhi thrust (figure 1). To the north of the Jawalamukhi Thrust (JMT), exists the asymmetrically folded Lambar gaon syncline (LS). Further to its north, the K4 seismic profile contains the Paror anticline (PA) that dies out to the south-east and has the similar tightly folded geometry of Sarkhaghat anticline (SA) in the east. The Palampur Thrust (PT) truncates Paror anticline and terminates against the Main Boundary Thrust (MBT, figure 1).
Dehradun is a structural depression bounded by the Lesser Himalayan range to the north truncated by the MBT and the Mohand anticline of Sub-Himalayan range truncated by the HFT to the south. Similarly, like the Kangra re-entrant, the Dehraudn re-entrant can be divided into two structural domains: the northern and the southern structures. In this paper, we have focused on a seismic profile (Doon-S profile) that lies to the south of the Mohand anticline. The HFT truncates the Siwalik strata at the northern part of the profile and transports the material upward. To the south east, the HFT is north-verging and breaks the crest of the Mohand anticline as the Bhimgoda backthrust (Karunakaran and Ranga Rao 1976; unpublished ONGC maps).

\section{Methodology}

\subsection{Modes of fault-related folds}

According to the active-hinge folding theory, the types of fault related folds can be determined in terms of their timing with respect to fault propagation (Suppe et al. 1990). There are three types of fault related folds:
A. Fault-bend fold (Snake head Antiform).
B. Fault-propagation fold.
C. Fault detachment fold (Lift-off fold).

Fault-bend fold is not simply slashed-up sections, but are stepped up section in the direction of tectonic transport. They exhibit a typical hanging wall deformation resulting from movement on a thrust having stair-case geometry composed of ramps and flats (Jamison 1987). The geometry (figure 2a) consists of a rear flat $(\mathrm{RF})$, footwall ramp (FWR), middle flat (MF), hanging wall ramp (HWR), and frontal flat (FF) (Suppe 1983; Lu et al. 1989). Fault-propagation folds (figure 2b) consist of an RF and FWR (Suppe et al. 1990). A key feature of these folds is that the fault shape constrains the fold shape. The fold develops simultaneously with the propagation of ramp immediately above the ramp and terminates when fault dies at the tip. Detachment folds also develop during movement of the hanging wall of a thrust fault, but here the fault is bed parallel, and not imbricated or stepped in shape. The geometric model for different types of fault related folds and the associated shortening can be used to examine and predict cross-sectional geometry of subsurface features. 

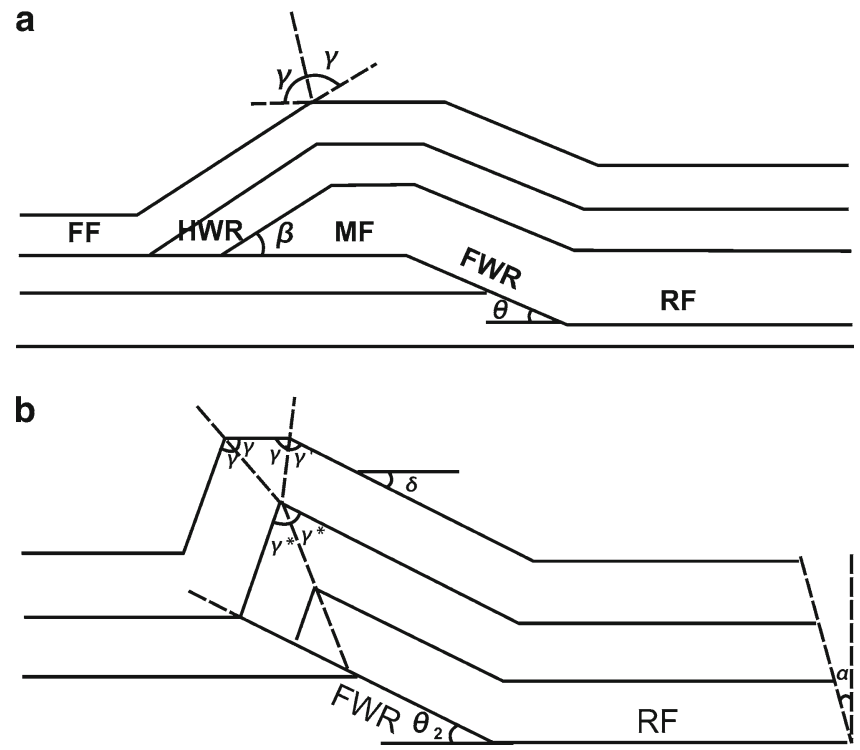

Figure 2. Geometric models of fault-related folds. (a) Fault-bend folds and (b) fault-propagation folds.

\subsection{Geometric analysis}

\subsubsection{Angular balancing}

The geometric relationships between folds and their underlying faults can be epitomized by diagrams of subsurface cross-sections of fault bend folds portraying various angles (figure 2a). Suppe (1983) defined angle $\theta$ as the cut-off angle formed as the fault ramp cuts across the beddings. The half-value of the inter-limb angle ' $\Upsilon$ is function of the fault bend angle $\Phi$ and cut-off angle $\theta$ (equation 1). This implies that the shape of the fold is controlled by the shape of the thrust plane. Also, $\beta$ is the final cut-off angle between the front limb of the anticline and fault plane of the hanging wall ramp, which is controlled by $\theta, \Phi$ and $\Upsilon$, as in equation (2) (Suppe 1983).

$$
\begin{aligned}
& \emptyset=\tan ^{-1}\left\{\frac{\sin (\gamma-\theta)[\sin (2 \gamma-\theta)-\sin \theta]}{\cos (\gamma-\theta)[\sin (2 \gamma-\theta)-\sin \theta]-\sin \gamma}\right\} \\
& \beta=\theta-\emptyset+\left(180^{\circ}-2 \gamma\right) .
\end{aligned}
$$

Similarly, for fault propagation folds, the geometric relationships are given by the following equations (Suppe et al. 1990):

$$
\begin{aligned}
\tan \alpha= & \frac{\sin \left(\gamma_{1}-\gamma^{*}\right)}{\sin \gamma_{1} \sin \gamma^{*}}+\frac{\sin \gamma^{*}}{\sin \gamma^{*} \sin 2 \gamma^{*}} \\
& -\frac{\sin \gamma_{1}}{\sin \gamma_{1} \sin \theta_{2}}, \\
& \theta_{2}+2 \gamma_{1}-180^{\circ}=0,
\end{aligned}
$$

where $\alpha$ is the angle of simple shear, in this case $\alpha=0^{\circ} . \Upsilon^{*}$ is half the value of the inter-limb angle in the axial plane angular anticline, $\Upsilon_{1}$ is the halfvalue of the inter-limb angle for the front limb of the bi-axial anticline, and $\theta_{2}$ is the cut-off angle on the footwall ramp (figure $2 \mathrm{~b}$ ).

Since both of these FBF and FPF are truncated against the thrust at their base (Jamison 1987), the shape of the fault bend fold and the fault propagation fold will depend on the shape of the underlying fault. This relationship can be represented graphically (Suppe 1983; Jamison 1987; Mitra 1990; Suppe et al. 1990). Assuming that the beds maintain their original thickness, Suppe (1983) represented a graph for fault-bend folds demonstrating the relationships between fold shape $\Upsilon$, fault bend angle $\Phi$, and cut-off angles $\theta$ and $\beta$ (figure 3a). For fault propagation folds, Suppe et al. (1990) defined the relationships between fold shape $\Upsilon$, fault bend angle $\Phi$, and cut-off angles $\theta_{1}$ and $\theta_{2}$ (figure $3 \mathrm{~b}$ ).

The geometric relationship between fault and fold shape can be used to examine the subsurface cross-sections (Chen et al. 2005). The process for testing seismic sections is as follows:

- Measure angles $\Upsilon, \beta, \Phi, \theta$, etc., from the seismic time section.

- Transform the seismic time section into a seismic depth section using scatter diagram of time-depth conversion (figure 3c) and measure the values of the angles again. Here, we have used the $\mathrm{P}$-wave velocities, corresponding to 

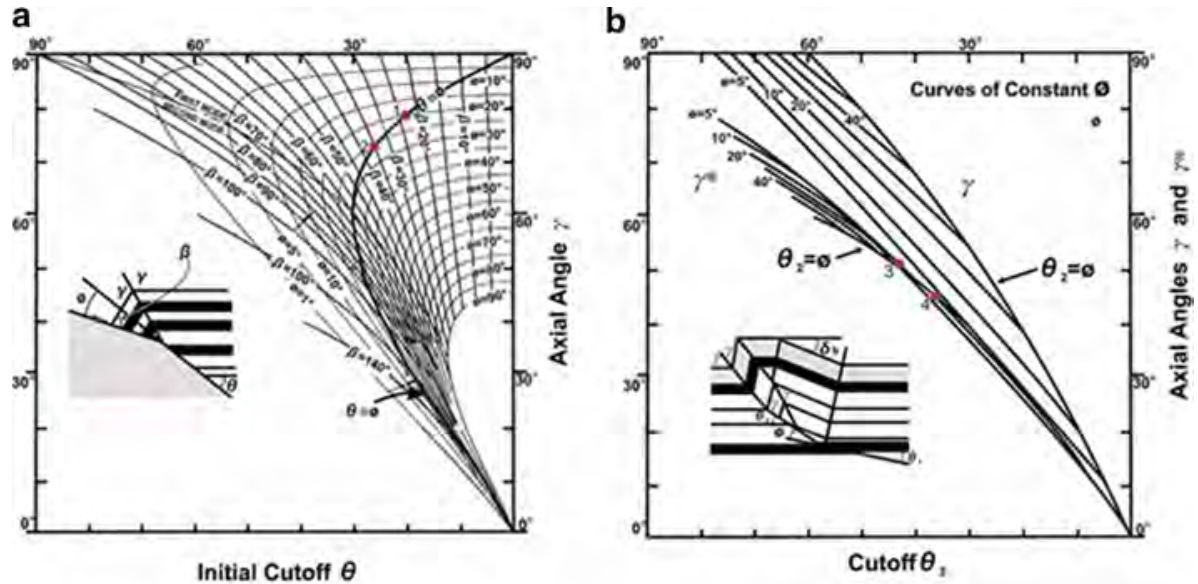

C Velocity profile for seiesmic time section to depth section conversion

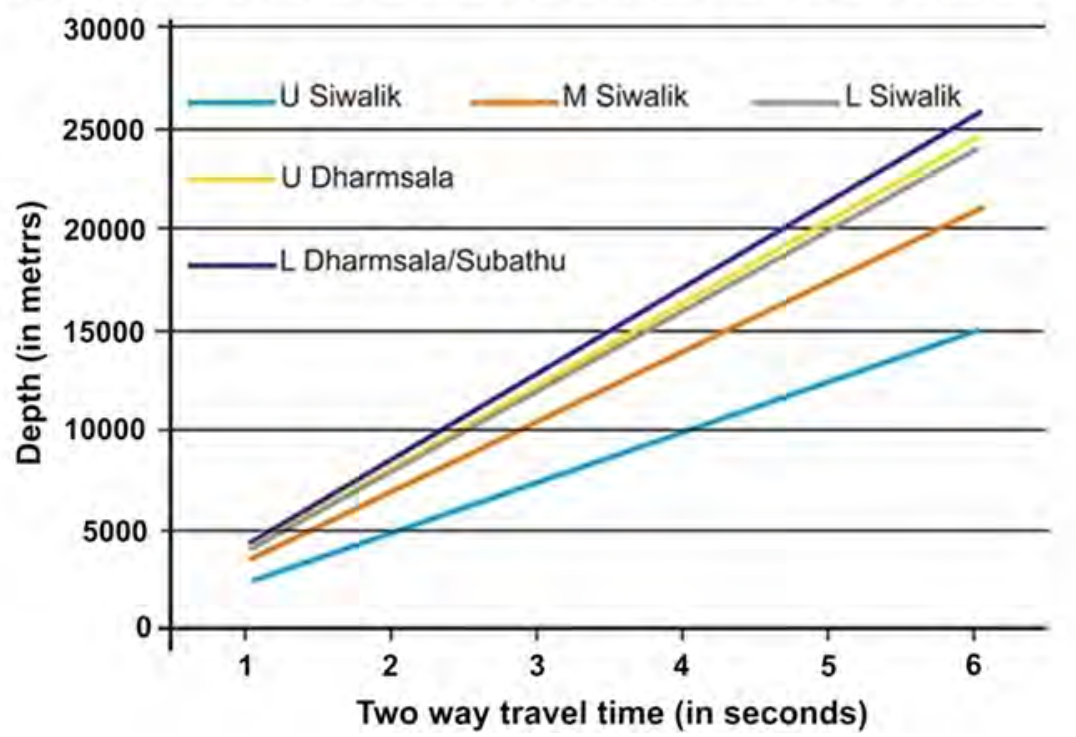

Figure 3. Tools for angular balancing method. (a) Curve showing the relationship between axial angle, ramp angle and cut-off angle for fault bend fold folds. Nos. 1 and 2 show the projection points of the cut-off angles for fault-bend folds of tables 2 and 4, respectively. (b) Curves showing the relationship between axial angle, ramp angle, and cut-off angle for a faultpropagation fold (after Suppe et al. 1990). Nos. 3 and 4 show the projection points of the cut-off angles of a fault-propagation fold of table 2c). The TWT-depth conversion graph for converting seismic time section to depth section corresponds to each Upper-Middle-Lower Siwalik and Upper-Lower Dharmsala unit. 'K4' seismic profile uses 'P-wave' velocity values of UpperLower Dharmsala strata to find out geometric measures correspond to Balh anticline, whereas 'K4' profile employs velocity curve for only Lower Dharmsala unit since the folded geometry is manifested by only Lower Dharmsala/Subathu strata.

Upper-Middle-Lower Siwalik and Upper-Lower Dharmsala units, as reported by Powers et al. (1998) in this study for geometric analysis in the NW Sub-Himalaya.

- The seismic section must be perpendicular to the structural line. Here, the regional structural trend is NNW-SSE and the seismic section used are roughly perpendicular to the overall trend, which is NE-SW. If this is not the case, then the values obtained must be translated to equivalent values in the perpendicular crosssection.
- Noting whether the fault bend angle $\Phi=\theta$, or not, from the graph, the theoretical values of the cut-off angles can be found out (figure $3 \mathrm{a}, \mathrm{b}$ ).

- Comparing the angles obtained in the seismic depth section with that of the theoretical values, if they match, the section is said to be balanced.

Here, the angular measurements are done in the footwall of fault-related folds, but it can also be determined in the hanging walls. The values are nearly the same in the case of Group-3 fault related 
structures as described by Williams and Chapman (1983) (see section 4).

\subsubsection{Shortening calculation by distance- displacement and fault angle measurement method}

Another method by Williams and Chapman (1983) can be employed to calculate the elongation and relative shortening of beds on either side of the fault plane (figure $4 \mathrm{a}$ ). This method requires choice of an arbitrary point, preferably at the tip of the fault. From this point, we measure the distance of a particular bed on the hanging wall $(L)$, and the amount of slip suffered by the bed on either side of the fault plane $(d)$ for each of the beds. Knowing the values of $d$ and $L$, elongation $(e)$ and relative stretch $\left(\epsilon_{r}\right)$ (Chapman and Williams 1984) can be calculated as:

$$
e=-d /(L+d)
$$

and

$$
\epsilon_{r}=L /(L+d) .
$$

Also, along a thrust plane, the amount of shortening can easily be calculated, if displacement along the fault plane is known to be ' $d$ ' and the fault angle is ' $\mu$ '.

$$
\text { Shortening }=d \text {. Cos } \mu \text {. }
$$

Based on the values of relative stretch, these structures (figure 4b) can be classified into three groups.

(1) Group 1: Relative stretch is at least $\sim 0.5$. This generally forms when thrust propagation rate is slower than the thrust slip rate (Elliott 1976).

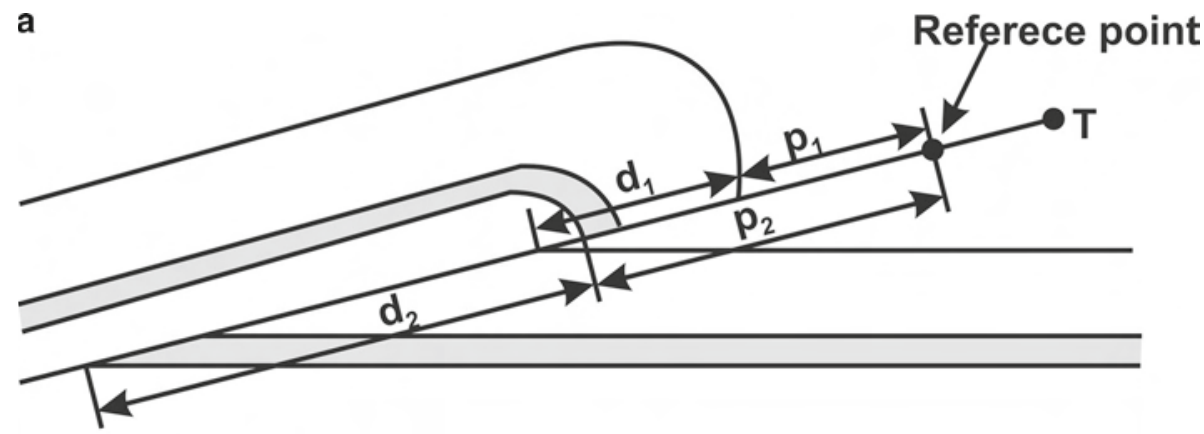

b

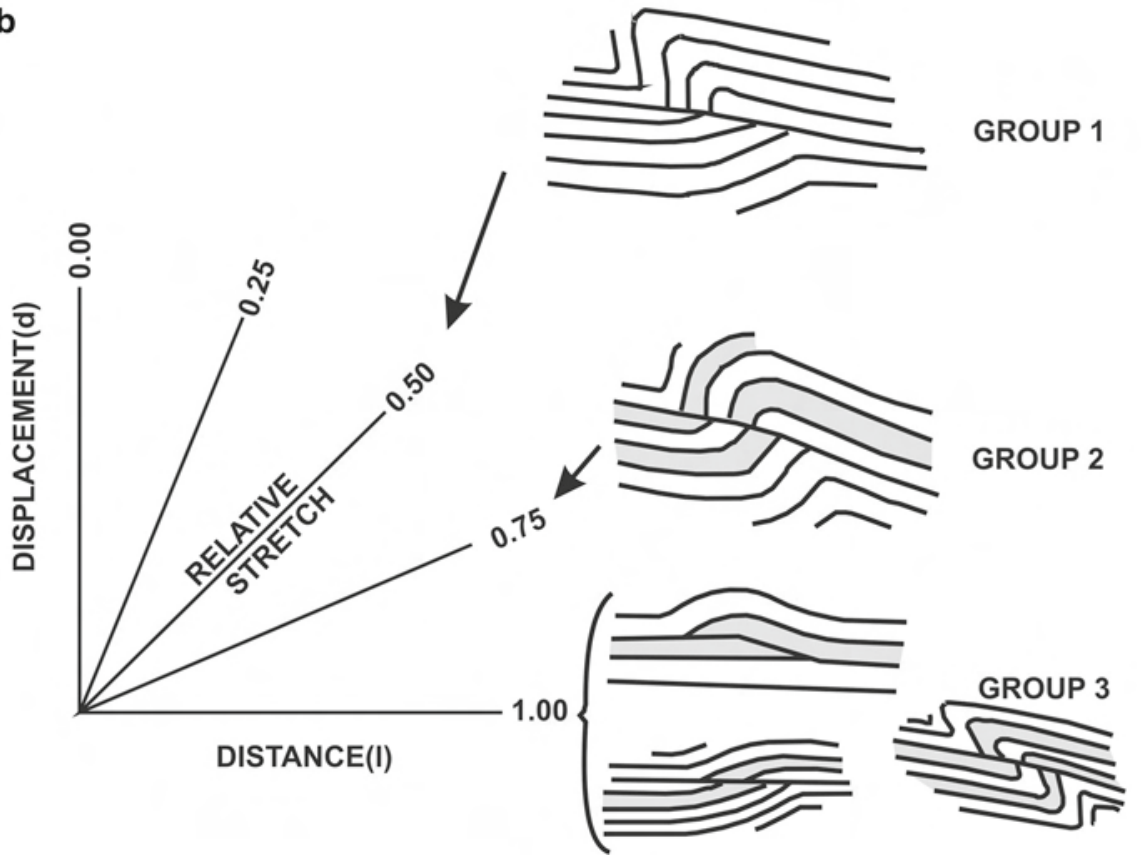

Figure 4. (a) Distance-displacement method along a fault plane showing displaced strata. (b) Relative stretching at different modes of fault related folding, note large amount of stretch related to ramp-flat geometry of Group-3 structure (after Williams and Chapman 1983). 
(2) Group 2: Relative stretch is around 0.75 (relative shortening 25\%). These folds grew well with advance of a propagating thrust, which then cut through at a fairly fast rate relative to fault slip. This modifies the fold profiles by further overturning of beds in the hanging wall immediately in front of the thrust.

(3) Group 3: Relative stretch is greatest $\sim 0.9$, and the shortening is very little, $\sim 10 \%$. Here, the hanging wall bed cut-offs match those in the foot wall. Most ramp flat structures fall in this group.

Thus, faults where slips of beds are much greater will have a low value of relative stretch $\left(\epsilon_{r}\right)$, signifying such structures will only possess thrusts, simply slashed up section above the fault plane. However, folds will be formed to accommodate the higher propagation rate compared to the lower slip rate. So the relative displacement should be of a lower order of magnitude in fault related folding.

\section{Seismic sections}

The study area forms the part of Kangra reentrant, an area in the Himalayan foothills between the Himalayan Frontal Thrust (HFT) and Main Central Thrust (MCT) comprising several splays of imbricated faults as discussed above and Dehradun
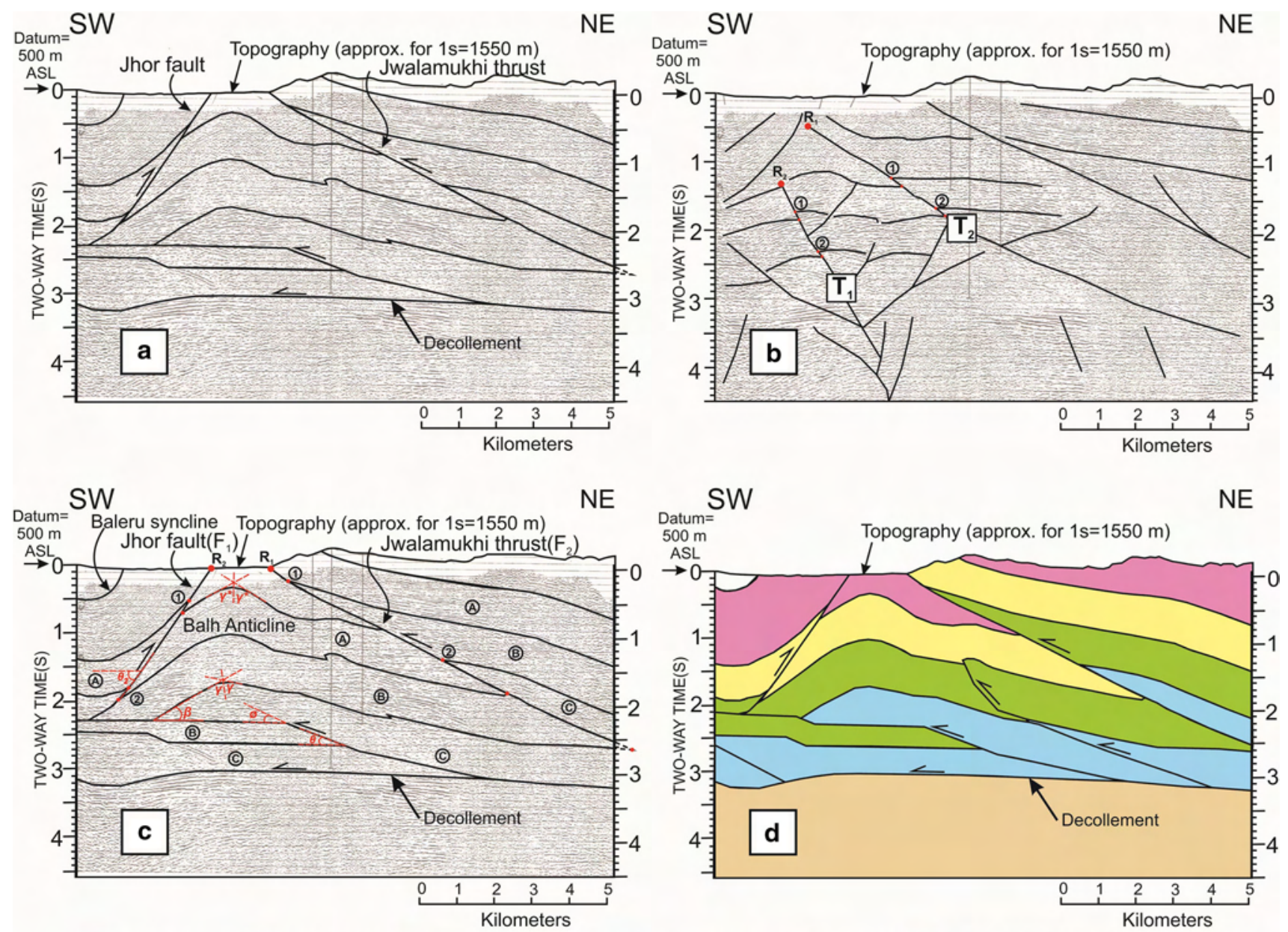

M Siwalik $\square$ L Siwalik $\square$ U Dharmsala

L Dharmsala/Subathu

PRE-TERTIARY Vindhyan

Figure 5. The sub-surface structures across the Kangra-2 seismic profile (line 'K2', figure 1). Line crosses the Jawalamukhi thrust along the A-A' line of section (figure 1). (a) The seismic profile across Kangra-2 as interpreted by Powers et al. (1998). (b) The same seismic profile as interpreted by Raiverman et al. Distance-displacement method has also been used on this profile considering $R_{1}$ and $R_{2}$ as reference points. (c) The interpreted seismic profile of Kangra-2 by angular balancing method with cut-off angle $\theta_{2} / \theta$ and axial angle $\Upsilon^{*} / \Upsilon$. Note the profile shows a fault-bend fold on 'F3' corresponding to $2-2.3 \mathrm{~s}$ in time section and fault-propagation fold on 'F1' at 0.4-1.8 s. (d) Jhor Fault and Jawalamukhi thrust with associated displaced stratal stratigraphy of Siwalik Himalaya. 
re-entrant resembling to the Kangra re-entrant with tightly folded Santaurgarh anticline at the north and broad Mohand anticline at the south.

Towards identification of precise structural features for seismic interpretation, a series of fault related folds are measured and tested by using both angular balancing and 'Dd' methods directly from the seismic profile. The seismic profile Kangra-2 (K2) is studied at first. This lies in the central part of the Kangra re-entrant and contains the SW vergent Balh anticline (BA) and Jawalamukhi Thrust (dip towards NE) in the subsurface. The second profile Kangra-4 (K4) constrains the subsurface geometry of NW trending Paror anticline and Palampur Thrust (vergence towards NE), which lies in the northern part of Kangra reentrant. Finally, Doon-S seismic section covers structural architectures of SW vergent Mohand anticline associated with HFT, which dips towards $\mathrm{NE}$ and southern zone of modern Indo-Gangetic foredeep.

\subsection{Kangra-2 seismic section}

Seismic profile of Kangra-2 as interpreted by Powers et al. (1998), displays the deformation is restricted to the Tertiary section where the decollement corresponds to 3.0-3.3 s (figure 5a). In time-depth conversion using the scatter plot of seismic wave velocities at different depth for different strata, the decollement depth comes out to be at $6 \mathrm{~km}$ (conversion illustrated in figure 3c). The seismic interpretation of Raiverman et al. (1994) and Raiverman (2002) did not explain this decollement, rather, two different faults presumably create a 'Flower structure' in depth (figure $5 \mathrm{~b}$ ). To perform geometric analysis of the Balh anticline in subsurface; the forelimb, the back limb and the fault ramp are approximated as straight lines. Making these approximations in the seismic time section (figure 5c), the measured initial cut-off angle $\Theta$ along 'F3' fault comes out as $18^{\circ}$ through time-depth transformation using velocity corresponds to Upper Dharmsala unit; $\Theta$ equals $21^{\circ}$ (table 2). The fault plane (F3) cuts the bedding planes of Lower and Upper Dharmsala, while the folded beds correspond to Lower-Upper Dharmsala and Lower Siwalik in age (figure $5 \mathrm{~d}$ ). Depth section conversion employs velocities at different depth for each of these strata (figure 3c) to accurately measure geometric values that correspond to Balh anticline. A southwest verging Jhor Fault $\left(\mathrm{F}_{1}\right)$ originates at $4.5-\mathrm{km}$ depth and cuts the folded strata while migrating upward. It also might have dragged the units along with it, possibly through reverse dragging mechanism (Grasemann et al. 2005; Mukherjee 2009, 2013c, 2014a,b).

By employing angular functions for the northern limb of Balaru syncline associated with ' $\mathrm{F}_{1}$ ' fault (figure $5 \mathrm{c}$ ), we found that $\Upsilon^{*}$ at the top of lower Siwalik strata is $58^{\circ}$. Transforming this value into an equivalent depth section from TWT (twoway travel time) time-depth curve of Lower Siwalik strata, the transformed axial angle was found to be $57^{\circ}$ (table 2).

\subsubsection{Distance-displacement method}

The distance-displacement (Dd) method along the Jhor fault $\left(\mathrm{F}_{1}\right)$ and the Jawalamukhi thrust $\left(\mathrm{F}_{2}\right)$ (figure $5 \mathrm{c}$ ) shows that the ' $\mathrm{F}_{1}$ ' fault plane is associated with lesser displacement of the strata (0.430 $\mathrm{km}$ ) relative to the ' $\mathrm{F}_{2}$ ' thrust where the slip is $\sim 5.98 \mathrm{~km}$ (table 3 ). The exact shortening amount can be obtained if the fault angle of ' $\mathrm{F}_{1}$ ' and ' $\mathrm{F}_{2}$ ' are taken as $57^{\circ}$ and $27^{\circ}$, respectively (using equation 6). The bulk of shortening experienced by the ' $\mathrm{F}_{2}$ ' fault plane $(6.06 \mathrm{~km})$ is higher than that of the ' $F_{1}$ ' plane $(0.26 \mathrm{~km})$. The ' $\mathrm{F}_{2}$ ' thrust did not allow the disrupted strata to accommodate the shortening by ductile deformation of the overlying beds. Thus, it has experienced significant orogenic contraction. Naturally, fault related folds do not undergo this significant shortening (Williams and Chapman 1983). When we apply the 'Dd' method on the interpreted seismic profile of Raiverman et al. (1993) and Raiverman (2002) (figure 5b), relative stretch values between 0.91 and 0.92 (table 3) associated with the ' $\mathrm{T} 1$ ' and ' $\mathrm{T} 2$ ' fault planes were obtained. This suggests that these structures fall under Group-3, i.e., fold thrust structure of Chapman (1983).

The two thrust system (F1 and F2) have opposite dip, one is dipping towards SW and the other towards NE. The Jawalamukhi thrust displays varying dips with homoclins in the upthrown block that employs surface material transport to the NE side. It indicates that a foreland propagating thrust system is inadequate to explain this structural architecture, rather in-sequence deformation at depth combined with out-of-sequence imbrications at upper structural levels is needed for its formation (Mukhopadhyay and Mishra 1999; Mukhopadhyay 2013). 
Table 2. Comparison and testing of cut-off angles for fault-bend and fault-propagation folds of Kangra re-entrant (K2 and K4 seismic profiles). See figures 5(c), 6(c) and sections 4.1, 4.2 in the main text for details.

\begin{tabular}{|c|c|c|c|c|c|c|}
\hline Studied area & Associated structure & $\begin{array}{c}\text { Measured } \\
\text { angles (degrees) }\end{array}$ & $\begin{array}{l}\text { Time } \\
\text { section }\end{array}$ & $\begin{array}{l}\text { Depth } \\
\text { section }\end{array}$ & $\begin{array}{c}\text { Theoretical } \\
\text { values }\end{array}$ & Inferred model \\
\hline \multirow[t]{3}{*}{ Kangra 2} & Balh anticline, associated Fault 'F3' & $\beta$ & 35 & 35 & 35 & Fault-bend-fold \\
\hline & & $\Theta$ & 18 & 21 & 24 & \\
\hline & & $\Upsilon$ & 68 & 71 & 72.5 & \\
\hline \multirow[t]{2}{*}{ Kangra 2} & $\begin{array}{l}\text { Northern limb of Balaru syncline } \\
\text { on Jhor Fault 'F1' }\end{array}$ & $\theta_{2}$ & 55 & 55 & 55 & Fault-propagation-fold \\
\hline & & $\Upsilon^{*}$ & 58 & 57 & 58 & \\
\hline \multirow[t]{2}{*}{ Kangra 4} & Paror anticline in subsurface & $\theta_{2}$ & 71 & 71 & 71 & Fault-propagation-fold \\
\hline & & $\Upsilon^{*}$ & 46 & 48 & 47 & \\
\hline
\end{tabular}

Table 3. Distance-displacement method to find out relative stretching and amount of displacement for seismic profile across Jawalamukhi and Balh Anticline (Kangra 2) as interpreted by Raiverman et al. (1994) and Powers et al. (1998). See figure 5(b) and section 4.1 in the main text for details $d=$ Slip along fault plane, $L=$ Distance of bed on hanging wall from arbitrary reference point, $e=$ Elongation $=-d /(L+d)$, and $\varepsilon r=$ Relative stretch $=L /(L+d)$.

\begin{tabular}{|c|c|c|c|c|c|}
\hline \multicolumn{3}{|c|}{ For Jhor fault plane $\left(\mathrm{F}_{1}\right)$} & \multicolumn{3}{|c|}{ For Jawalamukhi thrust $\left(\mathrm{F}_{2}\right)$} \\
\hline \multirow[b]{2}{*}{ Parameters } & \multicolumn{2}{|c|}{ Hanging wall cut-off points } & \multirow[b]{2}{*}{ Parameters } & \multicolumn{2}{|c|}{ Hanging wall cut-off points } \\
\hline & 1 & 2 & & 1 & 2 \\
\hline d (in km) & 0.430 & 0.430 & $\mathrm{~d}($ in $\mathrm{km})$ & 5.987 & 5.987 \\
\hline $\mathrm{L}($ in $\mathrm{km})$ & 1.045 & 3.873 & $\mathrm{~L}($ in $\mathrm{km})$ & 0.6168 & 5.184 \\
\hline $\mathrm{E}$ & -0.2915 & -0.0999 & $\mathrm{E}$ & -0.9066 & -0.5359 \\
\hline$\varepsilon \mathrm{r}$ & 0.7085 & 0.9001 & $\varepsilon \mathrm{r}$ & 0.0934 & 0.4640 \\
\hline \multicolumn{3}{|c|}{ For $T_{1}$ fault plane } & \multicolumn{3}{|c|}{ For $T_{2}$ fault plane } \\
\hline \multirow[b]{2}{*}{ Parameters } & \multicolumn{2}{|c|}{ Hanging wall cut-off points } & \multirow[b]{2}{*}{ Parameters } & \multicolumn{2}{|c|}{ Hanging wall cut-off points } \\
\hline & 1 & 2 & & 1 & 2 \\
\hline d (in km) & 0.347 & 0.347 & $\mathrm{~d}($ in $\mathrm{km})$ & 0.165 & 0.165 \\
\hline $\mathrm{L}($ in $\mathrm{km})$ & 2.530 & 3.941 & $\mathrm{~L}($ in $\mathrm{km}$ ) & 0.7789 & 2.014 \\
\hline $\mathrm{E}$ & -0.1206 & 0.0809 & $\mathrm{E}$ & -0.1748 & -0.0757 \\
\hline$\varepsilon r$ & 0.8794 & 0.9191 & $\varepsilon \mathrm{r}$ & 0.8252 & 0.9243 \\
\hline
\end{tabular}

\subsection{Kangra-4 seismic profile}

The seismic profile across Kangra-4 inherits the subsurface geometry of the Paror anticline and its corresponding decollement depth and dip. The Paror anticline is situated further north of the Lambargaon syncline. The southern limb of this anticline is steeper, whereas the northern limb changes its dip and becomes horizontal toward further north (figure 6a). The Paror anticline was interpreted as a fault propagation fold by Powers et al. (1998) that exhibits anticline breakthrough (figure 6a). The fault plane, starting from the basal decollement at a depth of $6.8 \mathrm{~km}$, branches upward and the strata of Subathu Unit rests above it (figure 6d). In contrast, a 'Positive Flower Structure' is portrayed by Raiverman et al. (1994) and Raiverman (2002) (figure 6b).
In the seismic section, the axial angle $\Upsilon^{*}$ at the top of Subathu strata is $46^{\circ}$ and cut-off angle $\Theta_{2}$ is $71^{\circ}$ (figure $6 \mathrm{c}$ ). In order to perform angular balancing, from an equivalent depth section, the axial angle is transformed in the TWT time-depth conversion curve for Subathu Strata and determined to be $48^{\circ}$ (table 2 ).

\subsection{Seismic interpretation of Doon-S profile of Doon re-entrant}

The major morphotectonic expression of the Main Frontal Thrust (MFT) or Himalayan Frontal thrust (HFT) is seen as an abrupt increase in the ground relative elevation, nearly $90 \mathrm{~m}$ from the alluvial plain. Barnes et al. (2011) demonstrates the ASTER GDEM fold topography to describe the relief, and it measures Mohand anticline as $\sim 80-\mathrm{km}$ 

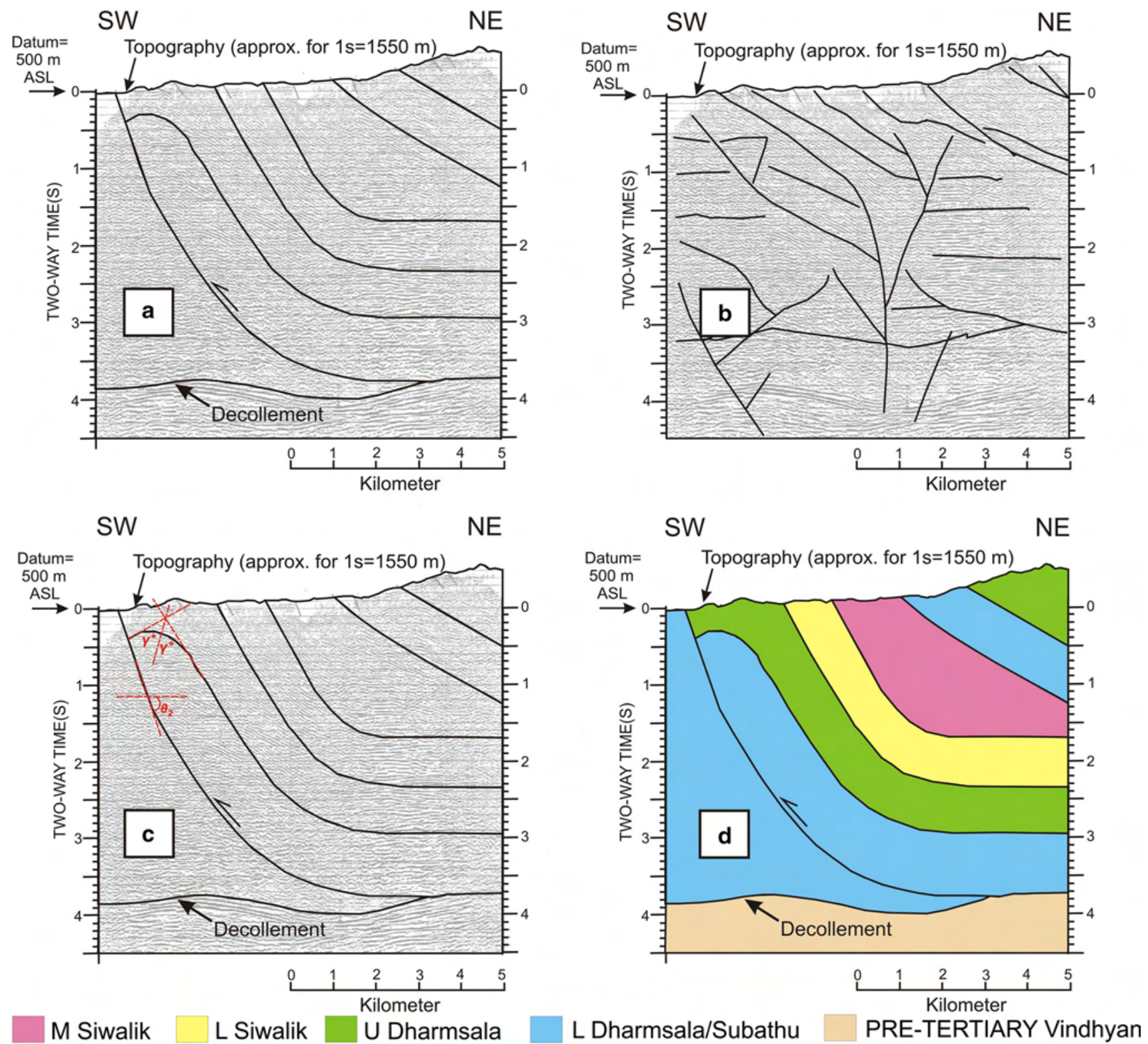

Figure 6. The sub-surface structures across the Kangra-4 seismic profile (line 'K4', figure 1). (a) The seismic profile across Kangra-4 as interpreted by Powers et al. (1998). (b) The same seismic profile as interpreted by Raiverman et al. (1994) and Raiverman (2002) showing positive flower structures. (c) The interpreted seismic profile by angular balancing method shows a fault propagation fold at subsurface responsible for the generation of Paror anticline. (d) Paror anticline with associated disrupted strata. Note the depth of decollement corresponds to $3.8 \mathrm{~s}$.

long and $\sim 15$-km wide, between the Yamuna and the Ganges Rivers, respectively (figure 7a). Here, thick black lines represent the drainage divide and white outlines stand for the hanging wall catchments. Barnes et al. (2011) have described the along and across strike variability of fold morphology and how they relate to the thrust at the base by examining catchment to hill slope scale variation in relief, drainage area, outlet variation and range half width. The B-B' profile along figure 7(a) shows a $13-\mathrm{km}$ wide swath averaged to minimum, maximum and mean elevation profile (SRTM-DEM)
(Barnes et al. 2011), and the lower one describes the balanced section (figure $7 \mathrm{~b}$ ) of Mukhopadhyay and Mishra (2004), where the undeformed, flat lying Siwalik and Dharmsala strata placed above a basement surface and the middle-upper Siwalik rocks get exposed as the Mohand Anticline uplifted (figure $7 \mathrm{~b}$ ). In the seismic profile of figure $7(\mathrm{c})$, more or less parallel strata with sub-horizontal dip towards south and moderately dipping strata towards the north suggests a prominent discontinuity at the subsurface, which is a fault. This fault is described as MFT 

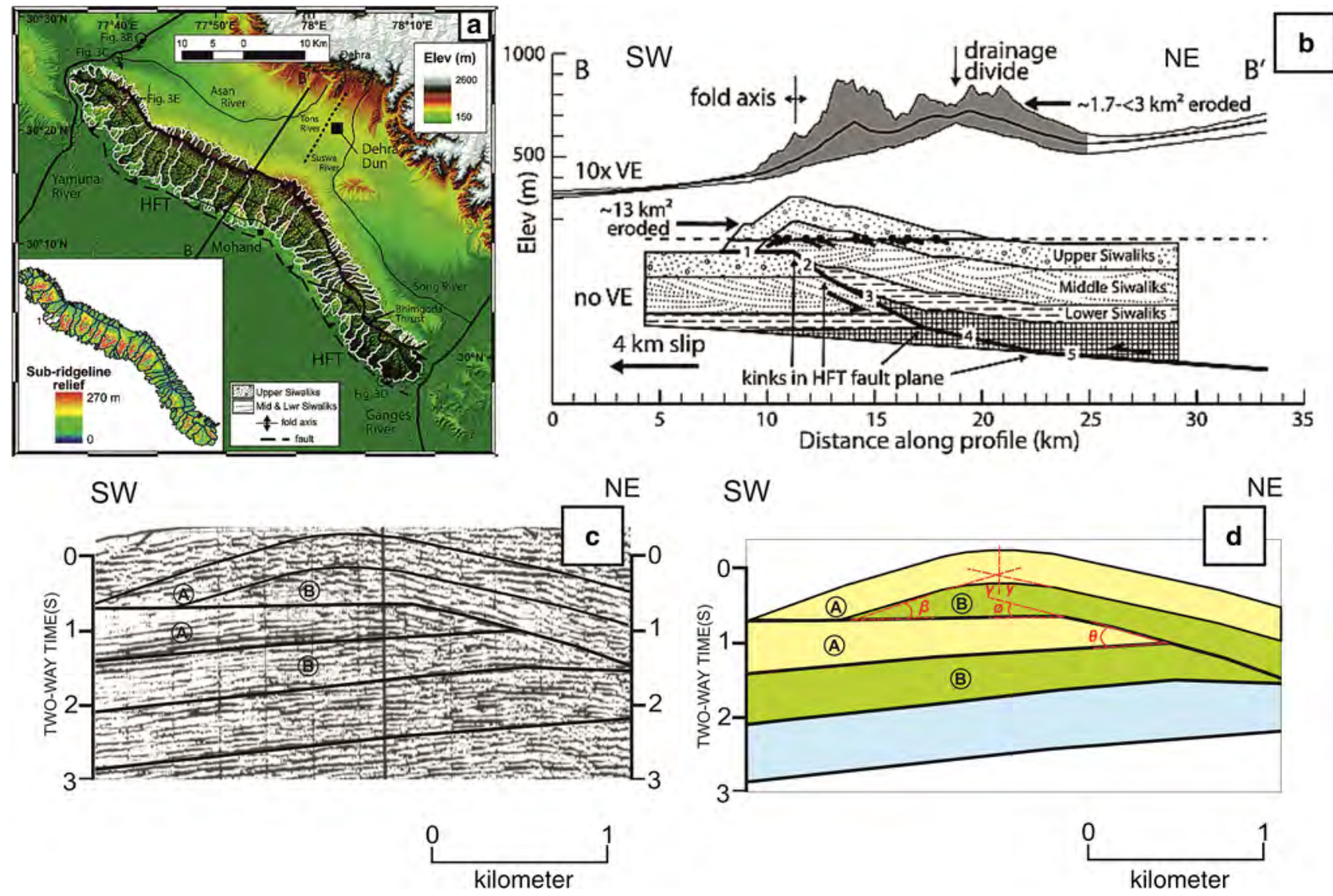

Figure 7. Investigation on Doon-S seismic profile (line 'DS' of figure 1). (a) Fold topography ASTER GDEM drainage divide, hanging wall catchments, fold axis from Barnes et al. (2011) and sub-ridgeline (hillslope-scale) relief (inset). (b) SRTM DEM Elevation profile from Barnes et al. (2011) above the balanced cross-section from Mukhopadhyay and Mishra (2004). Note the HFT formed kinks (1-5). (c) Seismic profile across Doon-S shows a fault bend fold delineated using angular balancing over a straight ramp discontinuity as marked by Powers et al. (1998). (d) The angular relationships and bed geometry over HFT. Note the beds are getting tilted progressively towards south.

having a ramp-flat geometry with kinks buried below the Gangetic alluvium (Mukhopadhyay and Mishra 2004; Barnes et al. 2011; figure 7b). But here we have used the seismic profile Doon-S and delineated the subsurface structure using our method of investigation over the straight-ramped HFT as marked by Powers et al. (1998). Previous authors have neither specified the thrust model nor the progressive evolution of the anticlines directly from the seismic profiles that could have given the first-hand information about any structures at depth.

The precise continuous trajectory of the HFT and the associated fold geometry in the hanging wall cannot be easily deduced from seismic profiles and lithologs (figure $7 \mathrm{c}$ ), but placing the dip domain data over the Doon-S seismic profile and conforming this model to the map pattern suggests that the Mohand anticline is a symmetrical, fairly open and upright fold (figure 7d). In reality, the Mohand anticline is asymmetric with S/SW vergence and northern limb much longer and gentler dipping than the southern limb (figure 7b, Barnes et al. 2011). Also, the surficial manifestation of a subsurface structure might be modified by different agents later on and also depends on the relative dominance of upliftment rate vs. erosion rate, etc. But here, if all the other factors are assumed to be constant, it can be seen that the surficial topography is not in conjunction with the subsurface structure. This discrepancy again seems to be caused by the kink geometry of HFT, which Powers et al. (1998) did not take into account. And, undoubtedly, it is very difficult to observe kinks in low resolution seismic data, so our initial proposed structure also confirms this symmetrical structure of Mohand anticline, since we had used the straight ramp model of Powers et al. (1998). But later on, the 'Dd' method clearly pointed out the flaws, 
Table 4. Angular balancing on Doon-S seismic profile shows cut-off angles related to fault-bend fold in subsurface. See figure 7 and section 4.3 in the main text for details.

\begin{tabular}{lccccc}
\hline Studied area & $\begin{array}{c}\text { Measured angles } \\
\text { (in degrees) }\end{array}$ & $\begin{array}{c}\text { Time } \\
\text { section }\end{array}$ & $\begin{array}{c}\text { Depth } \\
\text { section }\end{array}$ & $\begin{array}{c}\text { Theoretical } \\
\text { values }\end{array}$ & Model inferred \\
\hline Doon-S & $\beta$ & 17 & 21 & 23.5 & Ault-bend-fold \\
(inferred fold above MFT) & $\Theta$ & 22 & 22 & 21.5 & \\
& $\Upsilon$ & 71.5 & 75 & 78 \\
& $\Phi$ & 20 & 20 & 20 \\
\hline
\end{tabular}

while crosschecking the viability of our proposed structure.

Using the angular balancing, the cut-off angle $\Theta$ comes out to be $22^{\circ}, \beta=17^{\circ}$, and the axial angle (half of the inter-limb angle) $\Upsilon=71.5^{\circ}$ (figure $7 \mathrm{c}$ and $\mathrm{d}$ ). Converting the seismic time section into depth section using TWT-depth conversion curve for Middle Siwalik strata (figure 3c), the final cut-off comes out to be $21^{\circ}$ and $\Upsilon=75^{\circ}$. Theoretical value of final cut-off angle $\beta$ corresponds to $\Theta=22^{\circ}$ comes out to be $23.5^{\circ}$ (figure $3 \mathrm{a}$, point 2 ), which agrees well with the depth section value (table 4).

We also calculated the shortening along the MFT as drawn by Powers et al. (1998) for this profile (using equation 6). Assuming the ramp to be continuous, as described by Powers et al. (1998) and measuring the displacement of strata over this ramp having a $25^{\circ}$ dip, a mere $0.44 \mathrm{~km}$ shortening was found to be associated with the MFT. This shows an abrupt disagreement to the latest documented slip/shortening of $4 \mathrm{~km}$ across the Mohand anticline (Mishra and Mukhopadhyay 2002; Barnes et al. 2011).

\section{Discussion}

The geometric analysis of seismic sections provides the relative propagation rate of a thrust/fault with the associated fold architecture at depth and the amount of shortening. This displays scientifically driven unbiased subsurface structural network and provides a tool to check the retro deformability of a cross-section.

(A) For the Balh anticline in Kangra-2 seismic section (see section 4.1) the final cut-off angle $\beta=35^{\circ}$ in the Subathu unit agrees well with the theoretical values (table 2) of the initial cut-off angle $\Theta=24^{\circ}$ and axial angle $\Upsilon=72.5^{\circ}$ from Suppe's curve (1983) (figure $3 \mathrm{a}$, point 1 ). For the northern limb of the Balaru syncline associated with the Jhor Thrust, the geometric relationship in figure 3b (point 3) indicates that an angle $\Theta_{2}$ of $55^{\circ}$ is given for the axial angle $58^{\circ}$, which is consistent with the measured depth section value (table 2). So the presence of fault-bend fold is well established by analysing the seismic cross-section and this supports the visual interpretation of Powers et al. (1998) (figure 5c). For the Kangra-4 seismic section, the geometric relationship of the measured data for cut-off angle (see section 4.2) is consistent with the theoretical result (table 2, figure 3b, point 4). This implies that the Kangra-4 seismic profile must display a fault-related fold (figure $6 \mathrm{c}$ and $\mathrm{d}$ ), in contrast to the 'Positive Flower Structure' (figure 6b) of Raiverman et al. (1994) and Raiverman (2002). Applying the 'Dd' method on Raiverman's interpreted seismic profile (figure $6 \mathrm{~b}$ ), shortening associated with fault planes is found to be only $10 \%$ (section 4.1 and table 3), so the displacement must be accommodated by a fault-related fold architecture (figure 4b), as proposed by Chapman (1983). As per our calculation, the beds must display a ramp flat geometry, not the wrench faulting as deduced by Raiverman et al. (1994) and Raiverman (2002). Presence of fault related fold has already been established for this seismic section by exercising angular balancing method and it is congruous with the measurement done by the 'Dd' method.

Thus, in the orogenic contraction, structures can be accommodated by thrust or folding or by both, but a balanced cross section should remain consistent whenever we apply both these proposed methods. Our results suggest that both these methods demonstrate existence of fault-related folds associated with the Jhor fault and a slashed up section along the Jawalamukhi Thrust, which gains the 
credibility and is in consistence with the structural model proposed by Powers et al. (1998). Thus, the distance-displacement method serves as an additional abetment for the interpretation of seismic cross-section.

(B) From section 4.3, it is observed that there is a disparity between established shortening amount across the Mohand anticline and our studied value of only $0.44 \mathrm{~km}$ measured on the straight ramp of HFT as drawn by Powers et al. (1998). Though the fold geometry is properly getting balanced by the angular balancing method, measured shortening value shows a contradiction to the previous study of Mishra and Mukhopadhyay (2002) and by Barnes et al. (2011).

(C) As the amount of displacement along the fault plane is fixed and it can easily be measured directly from the seismic section, the only explanation of this contradiction may be a subtle change in the fault angle values (change in fault plane dip). Based on geometrical test in this study we interpreted the MFT as a multi-bend fault that assumes change in the 'Cosine' value associated with the ramp angle $(\mu)$ due to continued convergence (see equation 6), but earlier it was interpreted as a straight ramp geometry of the HFT by Powers et al. (1998). Synformal bends/kinks in the HFT (figure 7b) can lead to the large amount of shortening $(4-5 \mathrm{~km})$ of the hanging wall strata that initially started with the decollement slope and then more steepening of the fault plane took place (shallow to steep ramp). Taking this into account, the shortening as calculated on the multi-bend fault of figure 7 (b) comes out as $\sim 4.2 \mathrm{~km}$. The surficial manifestation of a subsurface structure might be modified by different agents later on and also depends on the relative dominance of upliftment rate vs. erosion rate, etc. But here if all the other factors are assumed to be constant, it can be seen that the surficial topography is not in conjunction with the subsurface structure. This discrepancy again seems to be caused by this kink geometry of HFT, which Powers et al. (1998) did not take into account. Undoubtedly it is very difficult to observe kinks in low resolution seismic data; thus our initial proposed structure also confirms this symmetrical structure of Mohand anticline, while using the straight ramp model of Powers et al. (1998). But later on, the 'Dd' method clearly pointed out the flaws while crosschecking the viability of our proposed structure. This multi-bend geometry of MFT beneath the Mohand anticline was previously interpreted by Mukhopadhyay and Mishra (2004) using cross-section balancing, by Barnes et al. (2011) using Shuttle Radar Topographic Mission-Digital elevation model (SRTM-DEM) topographic elevation profile. However, in this study, we have established the structural framework by employing only one universal simplified tool for investigation. Assuming a consistent shortening rate of $11.9 \pm 3.1 \mathrm{~mm} /$ year as estimated by Wesnousky et al. (1999), initiation age of the HFT is constrained between 460 and $290 \mathrm{ka}$ using maximum slip rate of $18 \mathrm{~mm} /$ year as proposed by Powers et al. (1998). Not only does the use and interpretation of Doon-S (DS) seismic profile using angular balancing and shortening measurements proves the cogency of this practice to interpret the associated fault geometry, but it also confirms that these two methods are mutually complementary. Each may have its own limitation but when exercised together they decipher subsurface geometry. The key is whenever the subsurface fold-fault geometry with the subsequent shortening amount as measured by geometric analysis mismatches each other and also disagrees with field observation, dip domain data, tectonic diagrams, balance cross section, etc., we must speculate that there is something, which we cannot attest using conventional fault-related fold structures. In many cases, it might not be possible to delineate structures precisely, but figuring out problems associated with foldfault architecture directly from seismic section can be done scientifically.

\section{Conclusions}

1. Angular balancing method, presuming conservation of area and bed length in cross-section can be successfully applied to examine the nature of fault-related folds within the Himalayan fold-thrust belts. The assumption of area conservation seems to be justified since the Siwalik range (Biswas et al. 2014) did not undergo any partial melting or melt intrusion at later stages of its evolution, thus volume area conservation remained. Though, shear heating 
has been estimated from brittle and ductile deformations (Mukherjee and Mulchrone 2012, 2013; Mulchrone and Mukherjee 2015; Mukherjee 2017), which can lead to melting and volume loss, no field evidence exists from Siwalik so far. We have converted the seismic-time crosssection into seismic-depth cross section in order to adjust the lost shape in time sections. These are very simplified and straightforward techniques of drawing subsurface features directly from seismic profiles and they provide important structural insights useful for the hydrocarbon industry.

2. The amount of displacement and relative stretching rate individually indicate the relative propagation rate of the fault and successive folding events. This may afford a qualitative method for determining the origin of fault-related folds. The seismic reflection configuration must be restored, if necessary.

3. The interplay between the angular balancing and distance-displacement method shows that there can be a straightforward and simple tool that can delineate sub-surface geometry. In more complex cases, where it is nearly impossible to mark the stratigraphic beds, the shortening can be estimated using excess area method, provided the depth of decollement is known.

4. Calculation of shortening acts as an additional tool where angular balancing can provide reliability and perfection to which the fault-related fold structures are drawn and interpreted. If a section is restored and well balanced by both these methods, then only the proposed model is satisfactory. Often one method checks the veracity and accuracy of the other; thus our proposed geometrical methods can be applied to the other Himalayan segments, e.g., Nepal, Bhutan and Eastern Himalayas.

\section{Acknowledgements}

This study was done while Joyjit Dey, Subham Sarkar and Anamitra Bhowmik were hosted by the Wadia Institute of Himalayan Geology (WIHG), Dehradun with Dr R Jayagondaperumal under the Indian Academy of Sciences (IAS)-SRFP-2015 summer fellow grant. Director, WIHG, Dehradun, is kindly acknowledged. Also, we are thankful to Dr Soumyajit Mukherjee (IIT Bombay), Simachal Padhy (NGRI, Hyderabad) for their detailed review and useful remarks. We are grateful to Oil and Nat- ural Gas Corporation (ONGC) for allowing us to use their seismic profiles. Last but not the least, we would also like to thank Dr N Purnachanda Rao, Associate Editor, JESS, for his help and support throughout this work.

\section{References}

Biswas T, Dutta and Mukherjee S 2014 Tectonics of Siwalik Himalaya in Dehradun-Roorkee section, India; GSA Annual Meeting in Vancouver, British Columbia (1922 October 2014), Topical Session: T.23 Exploring the Development of the Himalayan-Karakorum-Tibet Orogenic System from the Mantle to Mountain Peaks.

Barnes J B, Densmore A L, Mukul M, Sinha R, Jain V and Tandon S K 2011 Interplay between faulting and base level in the development of Himalayan frontal fold topography; J. Geophys. Res. 116(F03012) 1-19.

Chapman T J 1983 A guide to the structure of lower to middle Devonian Staddon grits and Jennyclif slates on the east side of Plymouth sound, Devon; Proc. Ussher Soc. 5 460-464.

Chapman T J and Williams G D 1984 Displacementdistance methods in the analysis of fold-thrust structures and linked-fault systems; J. Geol. Soc. 141(1) 121-128.

Chen J, Lu H, Wang S and Shang Y 2005 Geometric tests and their application to fault-related folds in Kuqa; J. Asian Earth Sci. 25 473-480.

Di Pietro, Joseph A and Kevin R P 2004 Tectonostratigraphic subdivisions of the Himalaya: A view from the west; Tectonics 23 1-23.

Dubey A K, Bhakuni S S and Selokar A D 2004 Structural evolution of the Kangra recess, Himachal Himalaya: A model based on magnetic and petro-fabric strains; J. Asian Earth Sci. 24 245-258.

Dubey A 2014 Understanding an Orogenic Belt: Structural evolution of the Himalaya; Springer Switzerland, pp. 267-314.

Elliott D 1976 The motion of thrust sheets; J. Geophys. Res. 81 949-963.

Gansser A 1964 Geology of the Himalayas (ed.) L U de Sitter, Wiley Interscience Publishers, New York, 289, 252.

Grasemann B, Martel S and Passchier C 2005 Reverse and normal drag along a fault; J. Struct. Geol. 27(6) 9991010.

Jamison W R 1987 Geometry analysis of fold development in overthrust terranes; J. Struct. Geol. 9(2) 207-219.

Jayangondaperumal R, Mugnier J L and Dubey A K 2013 Earthquake slip estimation from the scarp geometry of Himalayan Frontal Thrust, western Himalaya: Implications for seismic hazard assessment; Int. J. Earth Sci. 102 1937-1955.

Karunakaran C and Ranga Rao A 1976 Status of exploration for hydrocarbons in Himalayan region - contribution to stratigraphy and structure; Geol. Surv. India, Misc. Publ. 41 1-66.

Lu H, Dong H and Deng X 1989 Types and origins of the nappes in outer Longmenshan foreland basins; J. Nanjing University (Earth Sci.) 4 32-42 (in Chinese with English abstract). 
Mishra P and Mukhopadhyay D K 2002 Balanced structural models of Mohand and Santaurgarh ramp anticlines, Himalayan foreland fold-thrust belt, Dehra Dun Reentrant, Uttaranchal; J. Geol. Soc. India 60 649-661.

Misra A A and Mukherjee S 2017 Atlas of structural geological interpretation from seismic images; Wiley Blackwell, ISBN: 978-1-119-15832-5 (in press).

Mitra S 1990 Fault-propagation folds: Geometry and kinematic evolution, and hydrocarbon traps; Bull. Am. Assoc. Pet. Geol. 74 921-945.

Mukherjee S 2009 Channel flow, ductile extrusion and exhumation of lower mid-crust in continental collision zones; Curr. Sci. 89 435-436.

Mukherjee S and Koyi H A 2010a Higher Himalayan Shear Zone, Sutlej Section - Structural geology \& extrusion mechanism by various combinations of simple shear, pure shear \& channel flow in shifting modes; Int. J. Earth Sci. 99 1267-1303.

Mukherjee S and Koyi H A 2010b Higher Himalayan Shear Zone, Zanskar Section - Microstructural studies \& extrusion mechanism by a combination of simple shear \& channel flow; Int. J. Earth Sci. 99 1083-1110.

Mukherjee S, Koyi H A and Talbot C J 2012 Implications of channel flow analogue models for extrusion of the Higher Himalayan Shear Zone with special reference to the out-of-sequence thrusting; Int. J. Earth Sci. 101 $253-272$.

Mukherjee S and Mulchrone K F 2012 Estimating the viscosity and Prandtl number of the Tso Morari crystalline gneiss dome, Indian western Himalaya; Int. J. Earth Sci. 101 1929-1947.

Mukherjee S and Mulchrone K F 2013 Viscous dissipation pattern in incompressible Newtonian simple shear zones: An analytical model; Int. J. Earth Sci. 102 1165-1170.

Mukherjee S, Mukherjee B K and Thiede R C 2013 Geosciences of the Himalaya-Karakoram-Tibet orogen; Int. J. Earth Sci. 102 1757-1758.

Mukherjee S 2013a Higher Himalaya in the Bhagirathi section (NW Himalaya, India): Its structures, backthrusts and extrusion mechanism by both channel flow and critical taper mechanisms; Int. J. Earth Sci. 102 1851-1870.

Mukherjee S 2013b Channel flow extrusion model to constrain dynamic viscosity and Prandtl number of the Higher Himalayan Shear Zone; Int. J. Earth Sci. 102 1811-1835.

Mukherjee S 2013c Deformation Microstructures in Rocks; Springer Geochemistry/Mineralogy, Berlin, 111p.

Mukherjee S 2014a Review of flanking structures in mesoand micro-scales; Geol. Mag. 151 957-974.

Mukherjee S 2014b Atlas of shear zone structures in mesoscale; Springer Geol. Cham 1-124.

Mukherjee S 2015a A review on out-of-sequence deformation in the Himalaya, In: Tectonics of the Himalaya (eds) Mukherjee S, Carosi R, van der Beek P, Mukherjee B K, Robinson D; Geol. Soc. London Spec. Publ. 412 67-109.

Mukherjee S, Carosi R, van der Beek P A, Mukherjee B K and Robinson D M 2015b Tectonics of the Himalaya: An introduction (eds) Mukherjee S, Carosi R, van der Beek P A, Mukherjee B K and Robinson D M, Geol. Soc. London Spec. Publ. 412 1-3.
Mukherjee S 2017 Shear heating by translational brittle reverse faulting along a single, sharp and straight fault plane; J. Earth Syst. Sci. 126(1), doi: 10.1007/ s12040-016-0788-5.

Mulchrone K F and Mukherjee S 2015 Shear senses and viscous dissipation of layered ductile simple shear zones; Pure Appl. Geophys. 172 2635-2642.

Mukhopadhyay D K and Mishra P 1999 A balanced cross section across the Himalayan foreland belt, the Punjab and Himachal foothills: A reinterpretation of structural styles and evolution; Proc. Indian Acad. Sci. 108189 205.

Mukhopadhyay D K and Mishra P 2004 The Main Frontal Thrust (MFT), northwestern Himalayas: Thrust trajectory and hanging wall fold geometry from balanced cross sections; J. Geol. Soc. India 64 739-746.

Mukhopadhyay D K 2013 Exploration Strategy in the Himalayan foreland thrust belt; In: Petro-Conclave 2013, South East Asian J. Sedim. Basin Res. 1-2 3-9.

Nakata T 1972 Geomorphic history and crustal movements of the foot-hills of the Himalayas; Japan Institute of Geography, Tohoku University, pp. 173-174.

Najman Y, Clift P, Johnson M W R and Robertson A H F 1993 Early stages of foreland basin evolution in the Lesser Himalaya, N India; In: Himalayan tectonics (eds) Treloar P J and Searle M P, Geol. Soc. London Special. Publ. 74 541-558.

Powers M P, Lillie R J and Yeats R S 1998 Structure and shortening of the Kangra and Dehra Dun re-entrants, SubHimalaya, India; Geol. Soc. Am. Bull. 110 1010-1027.

Raiverman V, Kunte S V and Mukherjea A 1983 Basin geometry, Cenozoic sedimentation and hydrocarbon prospects in northwestern Himalaya and Indo-Gangetic plains; Pet. Asia J. 6 67-92.

Raiverman V, Srivastava A K and Prasad D N 1993 On the foothill thrust of northwestern Himalaya; J. Him. Geol. 4 $237-256$.

Raiverman V, Srivastava A K and Prasad D N 1994 Structural style in northwestern Himalayan foothills; Him. Geol. 15 263-280.

Raiverman V 2002 Foreland sedimentation in Himalayan tectonic regime: A relook at the orogenic process; Dehradun Bishen Singh Mahendra Pal Singh, pp. 117-123.

Seeber L, Armbruster J G and Quittmeyer R C 1981 Seismicity and continental subduction in the Himalayan arc; In: Zagros, Hindu Kush, Himalaya, geodynamic evolution (eds) Gupta H K and Delany F M, Am. Geophys. Union Geodyn. Ser. 3 215-242.

Srivastava P and Mitra G 1994 Thrust geometries and deep structure of the outer and lesser Himalaya, Kumaon and Garhwal (India): Implications for evolution of the Himalayan fold-and-thrust belt; Tectonics 13(1) 89-109.

Suppe J 1983 Geometry and kinematics of fault-bend folding; Am. J. Sci. 283 684-721.

Suppe J and Medwedeff D A Geometry and kinematics of fault-propagation folding; Ecol. Geol. Helv. 83(3) 409454.

Thakur V C (ed.) 1992 Geology of western Himalaya; Pergamon Press 19363.

Thakur V C, Joshi M, Sahoo D, Suresh N, Jayangondaperumal R and Singh A 2014 Partitioning of convergence in northwest sub-Himalaya: Estimation of late Quaternary 
uplift and convergence rates across the Kangra re-entrant, north India; Int. J. Earth Sci. (Geol. Rundsch) 103 1037-1056.

Wadia D N and West W D 1964 Structure of the Himalayas; Inter. Geol. Congress 22nd Session 10.

Wesnousky S G, Kumar S, Mohindra R and Thakur V C 1999 Uplift and convergence along the Himalayan Frontal Thrust of India; Tectonics 18 967-976.

Williams G D and Chapman T J 1983 Strains developed in the hanging wall of thrusts due to their slip/propagation rate, a dislocation model; J. Struct. Geol. 5 563571.

Yeats R S and Lillie R J 1991 Contemporary tectonics of the Himalayan frontal fault system: folds, blind thrusts and the 1905 Kangra earthquake; J. Struct. Geol. 13 215225 .

Corresponding editor: PuRnaCHANDRA RAO
Yeats R S, Nakata T, Farah A, Fort M, Mirza M A, Pandey M R and Stein R S 1992 The Himalayan Frontal Fault System; Ann. TectonicaeSuppl. 6 85-98.

Yin A 2006 Cenozoic tectonic evolution of the Himalayan orogen as constrained by along-strike variation of structural geometry, exhumation history, and foreland sedimentation; Earth-Sci. Rev. 76(1) 1-131.

Yin A, Dubey C S, Kelty T K, Gehrels G E, Chou C Y, Grove M and Lovera O 2006 Structural evolution of the Arunachal Himalaya and implications for asymmetric development of the Himalayan orogeny; Curr. Sci. 90(2) 195-200.

Zhao W, Nelson K D and Project INDEPTH Team 1993 Deep seismic reflection evidence for continental underthrusting beneath southern Tibet; Nature 366 557559. 